УДК 551.464

\title{
ТЕМПЕРАТУРНЫЕ ИЗМЕНЕНИЯ ВОДЫ И ВОЗДУХА ВДОЛЬ ПОБЕРЕЖЬЯ ПРИМОРСКОГО КРАЯ В СОВРЕМЕННЫЙ ПЕРИОД (северо-западная часть Японского моря)
}

\author{
Л. А. Гайко \\ ФГБУН Тихоокеанский океанологический институт им. В. И. Ильичева \\ ДВО РАН, г. Владивосток \\ E-mail: gayko@yandex.ru
}

\begin{abstract}
Проанализирована изменчивость среднегодовой температуры воды и воздуха по данным прибрежных гидрометеорологических станций Приморья за период наблюдений с 1930 по 2014 г.; выполнены сравнительный анализ колебаний среднемесячных температур за два последних десятилетия, а также сравнение температур каждого из четырех годов (с 2011 по 2014 г.) между собой и со средними значениями за первое десятилетие XXI в. По результатам проведенных исследований можно отметить, что вдоль побережья Приморского края за рассматриваемый период произошло увеличение среднегодовых температур воды и воздуха, при этом от года к году их среднемесячные значения могут значительно колебаться.
\end{abstract}

Ключевые слова: изменение климата, прибрежные гидрометеорологические станции, Приморье, температура воды, температура воздуха, температурный тренд, Японское море.

DOI: 10.34078/1814-0998-2019-2-29-37

\section{ВВЕДЕНИЕ}

Район исследования - северо-западное побережье Японского моря. Этот регион, расположенный в умеренных широтах, характеризуется муссонным характером атмосферной циркуляции с хорошо выраженными сезонами года (Климат..., 1983). Одной из ведущих проблем при исследовании климатических изменений по регионам является проблема взаимодействия океана и атмосферы, особенно в прибрежной зоне. Важную роль при изучении этого взаимодействия выполняет сеть гидрометеорологических станций, на которых проводятся регулярные наблюдения за температурой воды и воздуха. Эти параметры относятся к группе реперных при оценке климатической изменчивости.

По результатам мировых исследований (Изменение..., 2003; IPCC, 2001, 2003, 2007) последнее десятилетие прошлого века было самым теплым десятилетием столетия. Для прибрежных районов Приморья это подтверждается работами автора (Гайко, 2005, 2007, 2008). Кроме того, автор отмечает, что в первом десятилетии нынешнего века ряд высоких температур

(C) Гайко Л. А., 2019 для района исследования также продолжился (Gayko, 2012; Гайко, 2013, 2015).

Представляемая работа является результатом ведения температурного мониторинга в прибрежной зоне Приморья и содержит материалы исследования изменчивости температуры воды и воздуха по данным гидрометеорологических станций, расположенных вдоль побережья Приморского края. В работе дан анализ временного хода температуры воды и воздуха за период с 1930 по 2014 г., а также проведено сравнение хода среднемесячных температур последнего десятилетия прошлого (19912000 гг.) и первого десятилетия нынешнего (2001-2010 гг.) столетия между собой. Кроме того были выявлены особенности температурного режима в исследуемом районе за отдельные годы (с 2011 по 2014 г.) на фоне средних значений температуры воды и воздуха за первое десятилетие XXI в.

\section{МАТЕРИАЛ И МЕТОДЫ}

Для решения поставленных в работе задач использовали данные наблюдений над температурой воды и воздуха на пяти прибрежных гидрометеорологических станциях (ГМС), расположенных вдоль побережья Приморья: Посьет, 


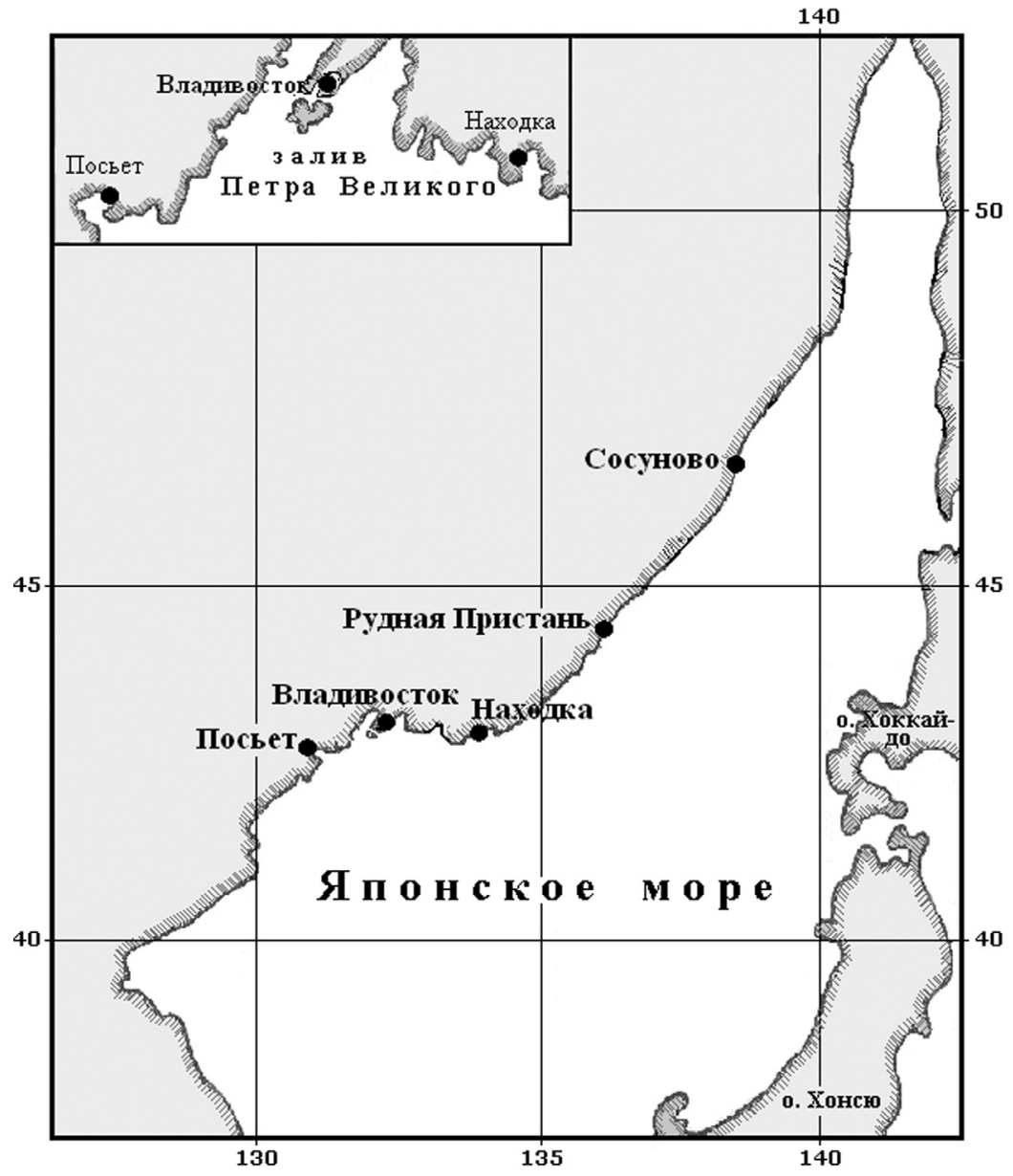

Puc. 1. Схема размещения гидрометеорологических станций на побережье Приморского края: ГМС Посьет, Владивосток, Находка, Рудная Пристань, Сосуново

Fig. 1. Location of coastal weather stations in the Primorsky Krai: Posyet, Vladivostok, Nakhodka, Rudnaya Pristan, Sosunovo

Владивосток, Находка, Рудная Пристань и Сосуново (рис. 1).

Для характеристики термических ресурсов климата в прибрежной зоне Приморского края использовали сведения о средней месячной температуре приземного воздуха и поверхности воды, которые были любезно предоставлены ФГБУ Приморское управление по гидрометеорологии и мониторингу окружающей среды. Оценка изменчивости температурного состояния акватории была проведена методами построения графиков и таблиц.

Выявление линейного тренда во временном ходе температуры воды и воздуха по станциям было проведено с помощью регрессионного анализа; оценка статистической значимости - с использованием критериев Стьюдента и Фишера. В качестве количественного критерия значения коэффициента корреляции на 5\%-ном уровне значимости для длительности рядов 80 лет принят $r_{\text {кр }} \geq 0.24$ (или $R^{2} \geq 0.058$ ).

\section{РЕЗУЛЬТАТЫ И ОБСУЖДЕНИЕ}

Межсгодвая изменчивость температуры за период 19302014 22. Для изучения межгодовой изменчивости для каждой станции были рассчитаны среднегодовые температуры воды и воздуха. По полученным данным были построены парные графики изменчивости температуры (рис. 2), позволяющие проследить изменение температуры воды и воздуха с 1930 по 2014 г. и провести сравнение хода этих температур между собой.

Судя по графикам (см. рис. 2), ход температуры прибрежных вод имеет более сложный характер, чем температуры воздуха; последний на всех станциях имеет довольно четко выраженную тенденцию роста. Можно также отметить, что только на ГМС Посьет кривые среднегодовой температуры воды и воздуха идут практически параллельно друг другу с ярко выраженной тенденцией повышения, на других станциях отмечается в большей или меньшей степени рассогласованность в их взаимоположении. Если рассматривать отдельно графики по каждой станции, то в ходе температуры воды можно выделить несколько периодов с различными тенденциями изменчивости. Так, на ГМС Владивосток анализ кривой показывает, что в 30-40-е гг. наблюдается повышение температуры воды, далее в 50-70-е гг. прослеживается некоторое ее понижение, а затем с начала 80-х гг. температура вновь начинает увеличиваться.

На станциях, расположенных на восточном побережье Приморья, картина хода температуры воды в общих чертах схожа с таковой на ГМС Владивосток, но размах межгодовых колебаний относительно тренда значительно больше, что связано, вероятно, с меандрированием Приморского течения, идущего с северо-востока вдоль побережья Приморья и влияющего на температурный режим прибрежных вод.

В юго-восточной части зал. Петра Великого в районе расположения ГМС Находка наблюдается несколько иная картина в распределении температур. Если в 30-40-е гг. ход температур здесь был аналогичен таковому на других станциях, то в 50-е гг. в Находке на фоне общего с другими станциями повышения температуры воздуха от- 


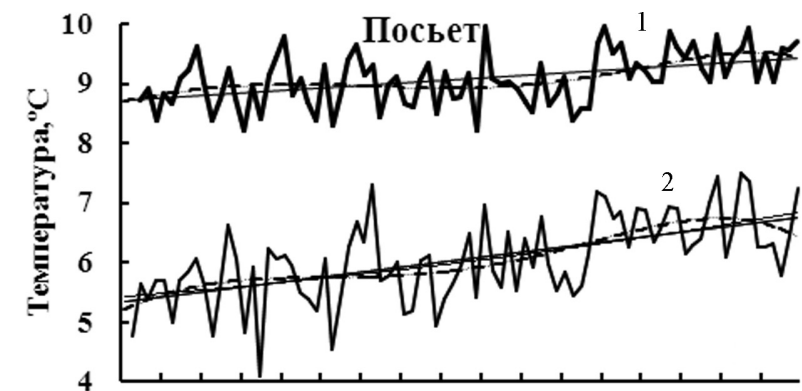

193019401950196019701980199020002010
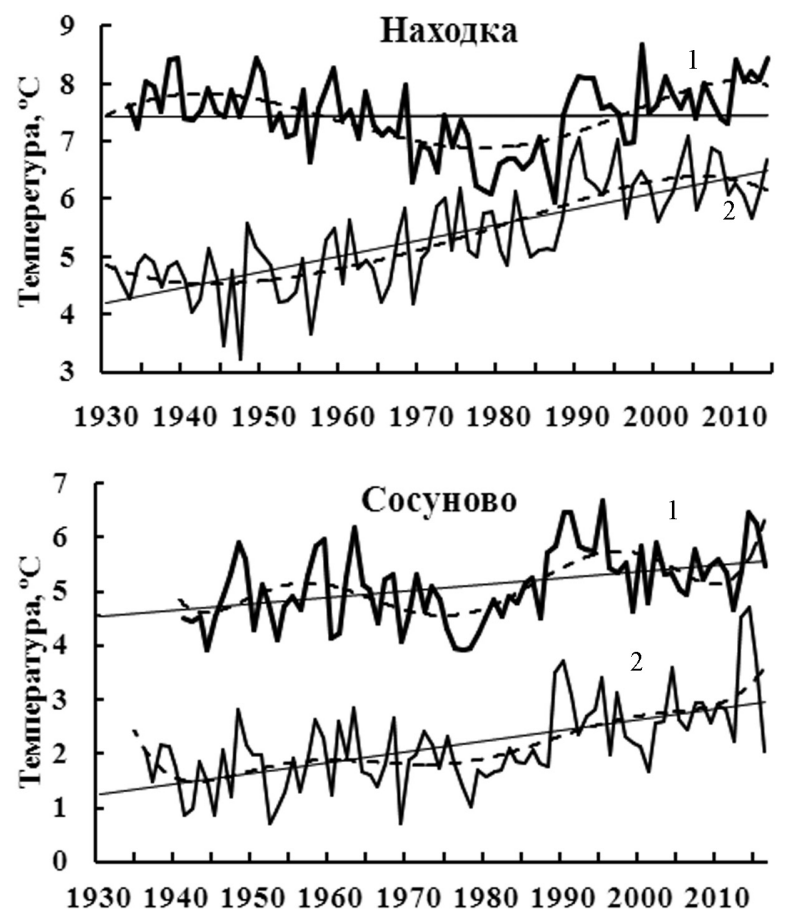

мечено продолжение понижения температуры воды, начавшееся в конце 40-х гг. Такая ситуация длится вплоть до начала 80-х гг. Судя по ходу полиномиального тренда с 1960 г. до начала 90-х гг., по данным станции в зал. Находка наблюдается понижение температуры воды, которое довольно четко иллюстрирует вогнутость линии хода температуры на графике (см. рис. 2). Возможно, что снижение температуры воды в указанный период является результатом усиления влияния на юго-восточную часть зал. Петра Великого холодного Приморского течения, которое, как известно, играет важную роль в формировании водных масс залива (Юрасов, Яричин, 1991; Данченков и др., 2003). Также на изменчивость температуры воды в юго-восточной части залива оказывает влияние активизация апвеллинга у юго-восточного побережья Приморья, вызывающего снижение общего температурного фона вод в районе исследования (Жабин и др., 1993; Гайко, 2005).

По-видимому, это связано с крупномасштабной перестройкой циркуляции Северного полушария, приходящейся на 70-е гг., которая послужила началом новой эпохи, характеризую-
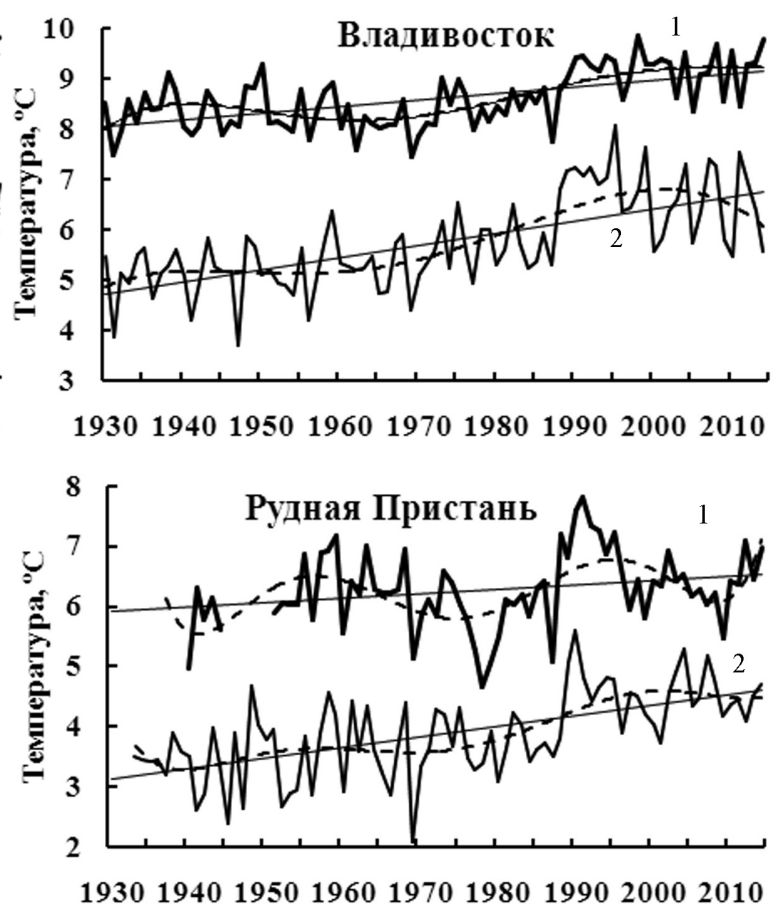

Puc. 2. Межгодовая изменчивость температуры воды (1) и воздуха (2) и их трендовые составляющие на ГМС Приморья (1930-2014 гг.)

Fig. 2. Inter-annual variability and trends of water (1) and air (2) temperatures at coastal weather stations in Primorye (1930-2014)

щейся превышением над нормой повторяемости определенных типов циркуляции (Смолянкина, 1999). Эти перестройки в атмосферных процесcax, произошедшие в 70-е гг, повлекли за собой и значительные изменения в циркуляции вод, что подтверждает отмеченное в 1982-1983 гг. очень мощное Эль-Ниньо (Волков, Калашников, 1990), в результате чего и в температурных характеристиках поверхностных вод отмечены изменения. Так, с начала 80-х гг. температура воды начала быстро расти вдоль всего побережья Приморья, особенно в районе ГМС Находка.

Во временном ходе среднегодовых температур воздуха таких резких различий между станциями не наблюдается, но можно отметить, что сам размах межгодовых колебаний температуры воздушных масс достигает больших величин, чем водных. Кроме того, в этот же период с 60-х до начала 90-х гг. на станциях Рудная Пристань и Сосуново прослеживается небольшая линза пониженной температуры воздуха. Такое распределение температуры воздуха может свидетельствовать о том, что в эти годы местные воздушные массы над юж- 
ной и восточной частями района исследования различались по температурным характеристикам. Возможно, это связано с влиянием на атмосферную циркуляцию орографии южного Приморья.

При анализе полученных результатов видно, что за период с 1960 по 1990 г. стабильный рост температуры воды и воздуха отмечался только в юго-западной части зал. Петра Великого. В его юго-восточной части, на ГМС Находка, стабильно росла только температура воздуха, а в ходе температуры воды в этот период наблюдалось значительное ее понижение с минимумом в 1982-1983 гг. На ГМС Владивосток и на восточном побережье Приморья этот период (19601990 гг.) характеризуется незначительным понижением температуры воды и воздуха, сглаженные кривые хода температур на графиках полиномом 5-й степени в этот период имеют вогнутую форму (см. рис. 2).

В целом при анализе временного хода среднегодовых значений и температуры воды, и температуры воздуха выявлен значимый на 5\%-ном уровне тренд, за исключением станции Находка, где в ходе температуры воды тренд не выявлен (табл. 1). Наблюдаемый рост среднегодовой температуры воздуха свидетельствует об общем увеличении температурного фона на изучаемой территории.

Сравнение среднемесячных температур последнего десятилетия XX и первого десятилетия XXI столетия. Сравнение температур, осредненных за 1991-2000 и 2001-2010 гг., было проведено отдельно для температуры воды и температуры воздуха для каждой прибрежной станции Приморья (табл. 2, рис. 3).

Таблица 1. Коэффициенты линейного тренда, аппроксимирующего составляющую температуры воды и воздуха (a, b), и коэффициент детерминации $\left(\mathrm{R}^{2}\right)$ на ГMC Приморья (1930-2014 гг.)

Table 1. Polynomial coefficients of the first degree approximating the trend components of water and air temperature $(a, b)$ and coefficient of determination $\left(R^{2}\right)$ at the coastal weather stations in Primorye (1930-2014)

\begin{tabular}{|l|l|l|l|l|l|l|}
\hline \multirow{2}{*}{ ГМС } & \multicolumn{3}{c|}{ Температура воды, ${ }^{\circ} \mathrm{C}$} & \multicolumn{3}{c|}{ Температура воздуха, ${ }^{\circ} \mathrm{C}$} \\
\cline { 2 - 7 } & $\mathrm{a}$ & $\mathrm{b}$ & $\mathrm{R}^{2}$ & $\mathrm{a}$ & $\mathrm{b}$ & $\mathrm{R}^{2}$ \\
\hline Посьет & 0.008 & 8.723 & $\mathbf{0 . 1 9 0}$ & 0.016 & 5.316 & $\mathbf{0 . 3 4 0}$ \\
\hline Владивосток & 0.013 & 8.032 & $\mathbf{0 . 3 2 9}$ & 0.024 & 4.708 & $\mathbf{0 . 4 4 8}$ \\
\hline Находка & 0.000 & 7.432 & 0.000 & 0.027 & 4.173 & $\mathbf{0 . 5 8 8}$ \\
\hline Рудная Пристань & 0.007 & 5.901 & $\mathbf{0 . 0 6 1}$ & 0.017 & 3.111 & $\mathbf{0 . 3 5 0}$ \\
\hline Сосуново & 0.011 & 4.542 & $\mathbf{0 . 1 3 3}$ & 0.019 & 1.205 & $\mathbf{0 . 3 4 4}$ \\
\hline
\end{tabular}

Примечание. Полужирным шрифтом обозначены значимые на 5\%-ном уровне коэффициенты.

Таблица 2. Величина отклонений среднемесячных температур, осредненных за период 1991-2000 гг., от температур, осредненных за период 2001-2010 гг., на ГМС Приморья

Table 2. Deviations of average monthly temperatures for the period 1991-2000 from the temperatures averaged for the period 2001-2010 at the coastal weather stations in Primorye

\begin{tabular}{|c|c|c|c|c|c|c|c|c|c|c|c|c|c|}
\hline \multirow{2}{*}{ ГМС } & \multicolumn{12}{|c|}{ Месяц } & \multirow[b]{2}{*}{ Год } \\
\hline & 1 & 2 & 3 & 4 & 5 & 6 & 7 & 8 & 9 & 10 & 11 & 12 & \\
\hline \multicolumn{14}{|c|}{ Отклонения температуры воды, ${ }^{\circ} \mathrm{C}$} \\
\hline$\Pi$ & 0.3 & 0.2 & 0.3 & 0.3 & -0.3 & -0.9 & 0.6 & -1.0 & -0.3 & 0.1 & -0.3 & 0.3 & -0.7 \\
\hline B & 0.6 & 0.4 & 0.4 & -0.5 & -0.6 & -0.9 & 0.4 & -0.1 & -0.2 & 0.9 & 0.8 & 0.6 & 1.8 \\
\hline $\mathrm{H}$ & 0.0 & -0.3 & 0.1 & -0.6 & -1.2 & -0.9 & -0.4 & -0.5 & 0.4 & 1.8 & -0.2 & 0.0 & -1.8 \\
\hline РП & 0.3 & 0.4 & 0.7 & 0.3 & 0.4 & 0.3 & -0.3 & -0.1 & 1.1 & 1.9 & 0.5 & 0.3 & 5.7 \\
\hline $\mathrm{C}$ & 0.0 & -0.3 & 0.0 & 0.3 & 0.4 & 0.3 & 0.2 & 0.6 & 0.4 & 2.0 & 0.6 & 0.2 & 4.7 \\
\hline \multicolumn{14}{|c|}{ Отклонения температуры воздуха, ${ }^{\circ} \mathrm{C}$} \\
\hline$\Pi$ & -0.3 & 0.7 & 0.2 & -0.3 & -0.2 & -1.2 & 0.8 & -0.8 & -0.4 & -0.2 & -0.1 & 1.0 & -0.7 \\
\hline B & -0.6 & 0.0 & 0.2 & 0.0 & -0.1 & -0.4 & 1.3 & -0.6 & -0.5 & 0.3 & 0.3 & 2.1 & 1.9 \\
\hline $\mathrm{H}$ & -0.3 & 0.4 & 0.1 & -0.6 & -0.3 & -1.4 & 0.5 & -0.9 & 0.1 & -0.1 & -0.4 & 1.1 & -1.8 \\
\hline РП & -0.3 & 1.2 & -0.2 & -0.1 & 0.2 & -1.1 & 0.1 & -0.9 & 0.2 & 0.1 & -0.4 & 0.6 & -0.7 \\
\hline $\mathrm{C}$ & -1.0 & 0.9 & -0.7 & 0.4 & 0.5 & -0.7 & 0.1 & -0.1 & 0.3 & 0.4 & -0.6 & -0.3 & -1.0 \\
\hline
\end{tabular}

Примечание. П - Посьет; В - Владивосток; Н - Находка; РП - Рудная Пристань; С - Сосуново; здесь и в табл. 3 серым цветом выделены отрицательные аномалии температуры.

Puc. 3. Внутригодовой ход усредненной по периодам 1991-2000 гг. (темная заливка) и 2001-2010 гг. (светлая заливка) температуры воды (слева) и воздуха (справа) на ГМС Приморья

Fig. 3. Intra-annual variability averaged over the periods 1991-2000 (black) and 2001-2010 (light) for water (left) and air temperature (right) at the coastal weather stations in Primorye 

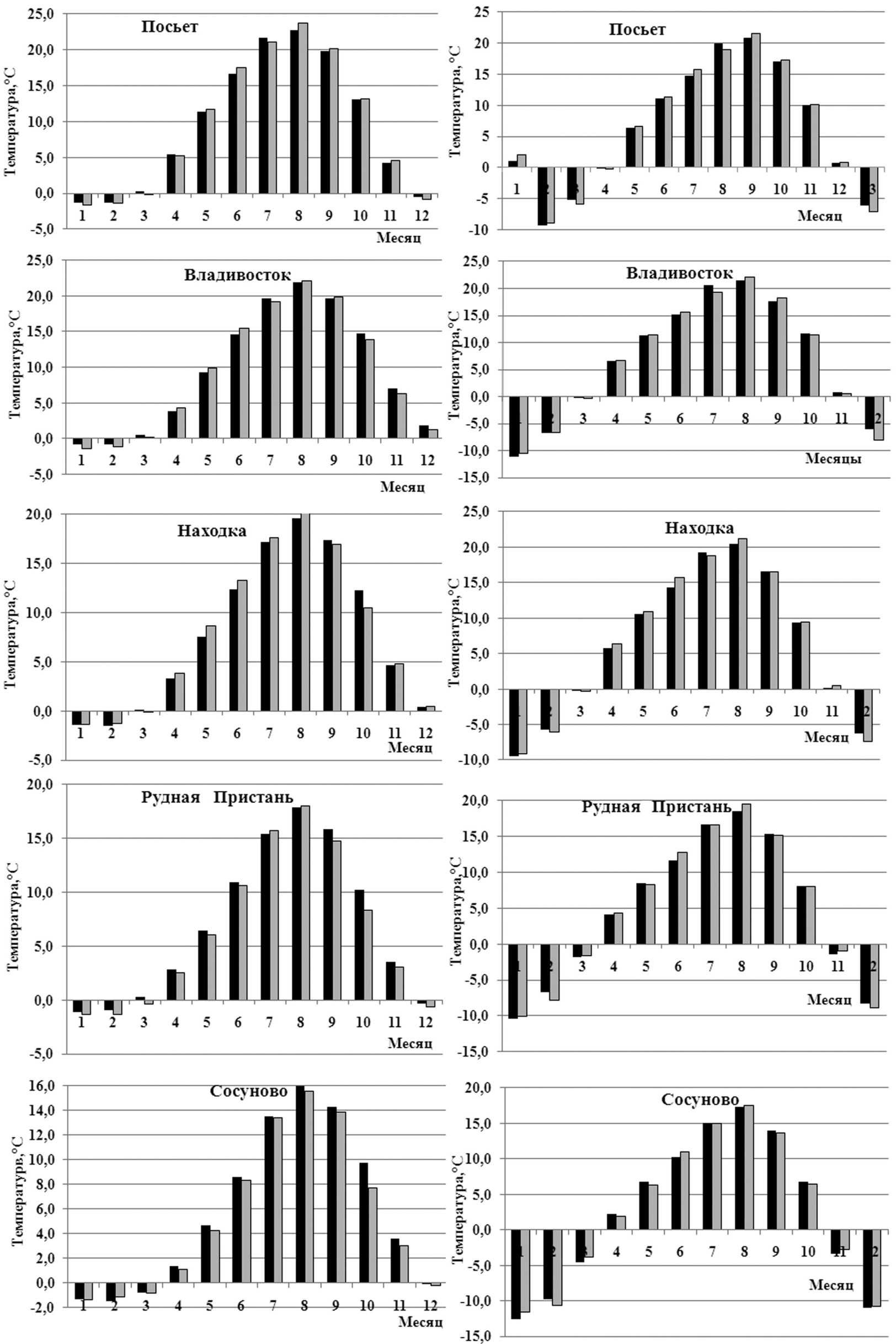
На основании анализа составленных по этим данным таблиц и построенных графиков можно отметить, что на ГМС Посьет средняя месячная температура воды в 90-е гг. в зимние и весенние месяцы была выше, чем в 2000-е гг., отклонения составили $0.2-0.3^{\circ} \mathrm{C}$. В летние и осенние месяцы, кроме июля и октября, температура воды в 90-е гг. была ниже, причем в июне и августе значительно.

Во Владивостоке в теплый период в 90 -е гг. температура воды была ниже, чем в 2000-е. В осенне-зимние месяцы, наоборот, в 90-е гг. выше, чем в 2000-е гг.

На ГМС Находка в 90-е гг. температура воды для большинства месяцев была ниже (в мае даже на $1.2^{\circ} \mathrm{C}$ ), чем в первое десятилетие 2000 -х; в 90-е гг. более высокая температура была отмечена в сентябре и октябре. Температура воды в январе, марте и декабре для обоих десятилетий была практически одинаковой.

На станциях восточного побережье Приморья средняя месячная температура воды в 1990-е гг. была выше почти во все месяцы, за исключением июля и августа на ГМС Рудная Пристань и февраля на ГМС Сосуново, где она была немного выше в 2000-е гг.

Средняя месячная температура воздуха на ГМС Посьет в 90-е гг. была выше, чем в 2000-е, всего в течение 4 мес: в феврале, марте, июле и декабре, причем в декабре на $1.0^{\circ} \mathrm{C}$ (см. табл. 2). Остальные месяцы были теплее в 2000-е гг. с максимальной амплитудой в июне и августе. На ГМС Владивосток характер распределения температуры воздуха зимой, весной и летом аналогичен таковому на ГМС Посьет, отличия только в величине отклонений. В 90-е гг. значительно теплее были июль и декабрь, а в 2000-е - январь и август. На ГМС Находка картина распределения температуры воздуха ближе к распределению температуры на ГМС Посьет. В Находке в 90-е гг. температура воздуха была выше в течение 5 мес, наибольшее ее превышение отмечено в январе, а в 2000-х гг. - в июне и августе. На ГМС Рудная Пристань и Сосуново половина месяцев года теплее в 1990-е гг. (на обеих станциях: февраль, май, июль, сентябрь и октябрь) с наибольшими отклонениями в феврале, в остальные месяцы года - в 2000-е гг. (на обеих станциях: январь, март, июнь, август и ноябрь) с наибольшими амплитудами в июне и августе на ГМС Рудная Пристань и в январе на ГМС Сосуново.

Анализ различий в температурах воды и воздуха между десятилетиями по сумме отклонений температур показал, что в целом на юге Приморья - в юго-западной (ГМС Посьет) и юговосточной (ГМС Находка) частях зал. Петра Великого, более теплыми были 2000-е гг., а в центральной части залива (ГМС Владивосток) - 90-е.
На восточном побережье Приморского края на станциях Рудная Пристань и Сосуново картина распределения температуры иная - температура воды выше в 1990-е гг., а температура воздуха - в 2000-е гг. (см. рис. 3, табл. 2), что связано, возможно, с меандрированием Приморского течения и местными особенностями циркуляции атмосферы.

Распределение температуры в 2011-2014 гг. и ее сравнение с температурой первого десятилетия XXI столетия. Для выявления особенностей распределения температуры в 2011, 2012, 2013 и 2014 г. было проведено сравнение среднемесячных температур за эти годы со среднемесячной температурой первого десятилетия XXI столетия. Для этого были рассчитаны для каждой прибрежной станции отклонения между среднемесячными температурами воды и воздуха за эти четыре года и среднемесячными температурами, осредненными за период с 2001 по 2010 г. По результатам вычислений была построена таблица, где серым цветом выделены отрицательные значения отклонений температуры (табл. 3). Проведем анализ этих результатов для каждой из сред.

Teмnepamypa воды. При анализе отклонений среднемесячной температура воды за эти 4 года по станциям закономерности в их распределении прослеживаются слабо. Из табл. 3 следует, что температура воды на всех станциях меньше всего претерпела изменения в янваpe - марте во все годы. В осенний период на всех станциях знак аномалий от года к году менялся: в 2011 г. - положительные, в 2012 г. отрицательные, в 2013 г. - в сентябре-октябре положительные, в ноябре-декабре - отрицательные, а в 2014 г. - наоборот. В 2014 г. с марта по июль практически на всех станциях отмечен рост температуры воды.

Анализируя табл. 3 по сумме отклонений за год, можно отметить, что в 2011 г. температура воды на ГМС Посьет и Владивосток была ниже, чем средняя за десятилетие 2001-2010 гг., на ГМС Находка и Рудная Пристань - немного выше, а на ГМС Сосуново равна среднепериодной температуре. В 2012 г. почти на всех станциях, за исключением ГМС Сосуново, температура воды была выше средней, а в 2013 и 2014 г. уже на всех станциях без исключения температура воды была выше средней за десятилетие, причем на ГМС Сосуново превышение составило $1.1^{\circ} \mathrm{C}$.

Teмnература воздуха. Больше всего в 2011 г. воздух прогрелся на ГМС Владивосток. Значительные отрицательные отклонения в этот год были отмечены на всех станциях в январе и мае, а в декабре исключение составила только ГМС Сосуново. В 2012 г. понижение температуры на ГМС Посьет наблюдалось в течение 9 мес, на ГМС Находка - 7 мес, на ГМС Рудная 
Таблица 3. Отклонения температуры воды и воздуха на ГМС Приморья (2001-2014 гг.)

Table 3. Deviations of the water and air temperature at coastal weather stations in Primorye (2001-2014)

\begin{tabular}{|c|c|c|c|c|c|c|c|c|c|c|c|c|c|c|}
\hline \multirow{2}{*}{ ГМС } & \multirow[b]{2}{*}{$\Delta \mathrm{T}$} & \multicolumn{12}{|c|}{ Месяц } & \multirow[b]{2}{*}{ Год } \\
\hline & & 1 & 2 & 3 & 4 & 5 & 6 & 7 & 8 & 9 & 10 & 11 & 12 & \\
\hline \multicolumn{15}{|c|}{ Отклонения температуры воды, ${ }^{\circ} \mathrm{C}$} \\
\hline \multirow{4}{*}{$\Pi$} & $\Delta \mathrm{T} 11$ & -0.1 & -0.1 & -0.3 & -0.9 & -2.3 & -0.4 & 1.0 & 0.3 & 0.2 & $\begin{array}{l}-1.8 \\
\end{array}$ & -0.5 & -0.2 & -0.4 \\
\hline & $\Delta \mathrm{T} 12$ & -0.1 & -0.2 & -0.2 & -1.0 & 0.8 & -1.7 & 0.7 & 0.3 & 0.9 & 1.4 & 0.9 & 0.0 & 0.2 \\
\hline & $\Delta \mathrm{T} 13$ & -0.2 & -0.3 & -0.4 & -1.4 & -1.3 & 0.7 & 1.7 & 1.1 & -0.2 & -0.1 & 0.7 & 0.8 & 0.1 \\
\hline & $\Delta \mathrm{T} 14$ & 0.5 & 0.0 & 0.8 & 1.6 & -1.3 & -1.2 & 2.2 & -0.1 & 0.2 & 1.0 & -0.1 & -0.6 & 0.0 \\
\hline \multirow{4}{*}{ B } & $\Delta \mathrm{T} 11$ & 0.0 & 0.3 & 0.4 & -0.7 & -1.2 & -1.6 & -0.3 & 0.1 & -2.0 & -1.5 & -0.7 & -0.8 & -0.7 \\
\hline & $\Delta \mathrm{T} 12$ & -0.2 & 0.1 & 0.3 & -1.3 & -0.2 & -0.8 & 0.1 & -1.0 & 0.2 & 2.1 & 1.0 & 1.5 & 0.2 \\
\hline & $\Delta \mathrm{T} 13$ & 0.1 & -0.2 & -0.1 & -0.9 & -0.3 & 0.9 & 0.3 & 1.0 & -0.7 & $\begin{array}{l}-0.8 \\
\end{array}$ & 1.7 & 1.5 & 0.2 \\
\hline & $\Delta \mathrm{T} 14$ & 0.4 & -0.1 & 0.4 & 1.1 & 1.1 & 1.8 & 3.0 & 0.8 & -0.2 & 0.8 & $\begin{array}{l}0.1 \\
\end{array}$ & -1.0 & 0.7 \\
\hline \multirow{4}{*}{$\mathrm{H}$} & $\Delta \mathrm{T} 11$ & 0.2 & 0.3 & 0.7 & 0.7 & 0.1 & 0.9 & 1.6 & 1.4 & 0.7 & -2.4 & -1.4 & -0.1 & 0.2 \\
\hline & $\Delta \mathrm{T} 12$ & -0.1 & -0.3 & -0.7 & -0.6 & 0.3 & 0.7 & 0.4 & -0.4 & 1.8 & 2.3 & 1.6 & 0.2 & 0.4 \\
\hline & $\Delta \mathrm{T} 13$ & -0.1 & -0.1 & -0.6 & -1.7 & -0.5 & 0.9 & 1.0 & 0.7 & 0.0 & -0.9 & 2.7 & 1.9 & 0.3 \\
\hline & $\Delta \mathrm{T} 14$ & 0.2 & -0.2 & 2.4 & 1.1 & 0.7 & 1.3 & 2.0 & -0.4 & 1.7 & 1.3 & -1.5 & -0.8 & 0.6 \\
\hline \multirow{4}{*}{ РП } & $\Delta \mathrm{T} 11$ & -0.1 & 0.1 & 0.6 & 1.2 & 0.2 & 0.3 & 0.4 & -0.7 & -0.2 & -0.9 & 0.8 & -0.6 & 0.1 \\
\hline & $\Delta \mathrm{T} 12$ & -0.3 & -0.3 & -0.3 & -0.2 & 0.8 & 1.4 & 0.0 & 0.0 & 2.2 & 3.6 & 2.4 & 0.5 & 0.8 \\
\hline & $\Delta \mathrm{T} 13$ & -0.2 & -0.3 & -0.5 & -0.4 & -0.1 & 1.2 & 0.0 & 0.5 & -0.9 & -1.1 & 2.0 & 1.7 & 0.2 \\
\hline & $\Delta \mathrm{T} 14$ & -0.1 & -0.1 & 0.6 & 2.3 & 1.3 & 1.3 & 1.6 & -1.2 & 2.1 & 1.9 & -0.7 & -0.6 & 0.7 \\
\hline \multirow{4}{*}{$\mathrm{C}$} & $\Delta \mathrm{T} 11$ & 0.1 & -0.1 & 0.2 & 0.5 & -0.6 & -0.8 & -2.1 & -1.2 & -1.4 & 1.0 & 2.6 & 1.9 & 0.0 \\
\hline & $\Delta \mathrm{T} 12$ & 0.3 & -0.4 & -0.4 & -0.6 & -0.2 & -1.7 & -2.7 & -2.8 & -1.3 & 1.3 & $\begin{array}{l}0.4 \\
\end{array}$ & -0.2 & -0.7 \\
\hline & $\Delta \mathrm{T} 13$ & -0.4 & -0.6 & -0.2 & 0.6 & 0.0 & -0.9 & -0.4 & 1.9 & -1.9 & -2.5 & 2.4 & 2.8 & 0.1 \\
\hline & $\Delta \mathrm{T} 14$ & 1.3 & 0.3 & 1.3 & 2.3 & 1.8 & 1.7 & 1.4 & -1.3 & 1.6 & 2.2 & 0.9 & 0.2 & 1.1 \\
\hline \multicolumn{15}{|c|}{ Отклонения температуры воздуха, ${ }^{\circ} \mathrm{C}$} \\
\hline \multirow{4}{*}{$\Pi$} & $\Delta \mathrm{T} 11$ & -2.4 & 0.7 & -0.2 & -0.6 & -2.3 & -0.6 & 0.3 & 0.3 & -0.1 & 0.5 & 0.9 & -1.3 & -0.4 \\
\hline & $\Delta \mathrm{T} 12$ & -2.0 & -2.5 & -0.6 & -1.4 & -0.2 & -2.0 & 0.3 & -0.7 & 0.6 & -0.1 & 0.3 & -3.0 & -0.9 \\
\hline & $\Delta \mathrm{T} 13$ & -1.8 & -3.2 & -1.2 & -1.6 & -0.4 & -0.3 & 1.8 & 0.6 & 0.0 & 0.5 & 1.3 & 1.3 & -0.3 \\
\hline & $\Delta \mathrm{T} 14$ & -0.1 & -1.8 & 1.5 & 2.1 & 0.7 & 0.4 & 2.9 & 0.2 & -0.2 & 0.1 & 2.3 & -1.7 & 0.5 \\
\hline \multirow{4}{*}{ B } & $\Delta \mathrm{T} 11$ & -1.9 & 2.0 & 1.8 & 0.8 & -0.4 & 1.1 & 2.3 & 1.8 & 0.7 & 1.6 & 1.7 & -0.4 & 0.9 \\
\hline & $\Delta \mathrm{T} 12$ & -2.4 & -0.4 & 1.1 & 0.7 & 1.5 & 0.3 & 2.2 & 0.3 & 1.1 & 0.7 & 1.8 & -3.0 & 0.3 \\
\hline & $\Delta \mathrm{T} 13$ & -3.5 & -2.3 & -0.6 & -1.3 & -0.7 & 0.9 & 2.1 & 1.5 & 0.8 & -2.0 & 2.4 & $\begin{array}{l}-0.3 \\
\end{array}$ & -0.3 \\
\hline & $\Delta \mathrm{T} 14$ & -1.4 & -4.1 & -0.4 & 0.5 & 0.0 & 0.1 & 1.8 & -1.3 & -1.5 & -2.3 & -0.2 & -3.8 & -1.1 \\
\hline \multirow{4}{*}{$\mathrm{H}$} & $\Delta \mathrm{T} 11$ & -2.4 & 1.7 & -0.6 & -0.7 & -2.0 & -0.6 & 0.7 & 0.9 & 0.0 & 0.4 & 0.4 & -1.5 & -0.3 \\
\hline & $\Delta \mathrm{T} 12$ & -2.5 & -2.4 & -0.5 & -0.8 & 0.2 & -1.1 & 0.4 & -0.6 & 1.6 & 0.1 & 0.4 & -3.7 & -0.7 \\
\hline & $\Delta \mathrm{T} 13$ & -2.3 & -2.3 & -1.3 & -1.9 & -1.0 & 0.0 & 1.7 & 0.8 & 0.0 & 0.3 & 1.2 & 2.0 & -0.2 \\
\hline & $\Delta \mathrm{T} 14$ & -0.6 & -1.6 & 1.1 & 1.5 & 0.9 & 0.5 & 2.1 & -0.4 & 0.5 & 0.2 & 1.7 & -2.4 & 0.3 \\
\hline \multirow{4}{*}{ РП } & $\Delta \mathrm{T} 11$ & -1.9 & 2.1 & 0.0 & 0.5 & -2.5 & -1.2 & 0.4 & 1.2 & 0.0 & 0.3 & 0.7 & -1.0 & -0.1 \\
\hline & $\Delta \mathrm{T} 12$ & -2.4 & -1.8 & -0.7 & -0.8 & -0.3 & -1.1 & 0.5 & -0.1 & 1.9 & 0.1 & 1.2 & -2.3 & -0.5 \\
\hline & $\Delta \mathrm{T} 13$ & -2.5 & -1.5 & -1.8 & -0.5 & -1.7 & 1.5 & 1.8 & 0.3 & -0.5 & 0.0 & 1.5 & 2.7 & -0.1 \\
\hline & $\Delta \mathrm{T} 14$ & -1.4 & -0.2 & 0.7 & 1.7 & 0.9 & 0.5 & 1.4 & -1.6 & 0.4 & -0.3 & 1.4 & -2.0 & 0.1 \\
\hline \multirow{4}{*}{ C } & $\Delta \mathrm{T} 11$ & -0.5 & 2.8 & 0.4 & 0.2 & -2.7 & -1.0 & 0.3 & 0.8 & -0.8 & 0.6 & 0.7 & 0.8 & 0.1 \\
\hline & $\Delta \mathrm{T} 12$ & -2.2 & -1.9 & -1.8 & -0.6 & 0.1 & -0.7 & 0.0 & 0.0 & 1.2 & 0.4 & 1.3 & -1.4 & -0.5 \\
\hline & $\Delta \mathrm{T} 13$ & -1.3 & 0.8 & 0.6 & 2.1 & 0.0 & 1.2 & 3.1 & 2.1 & 2.2 & 2.5 & 4.7 & 4.4 & $\begin{array}{l}1.9 \\
\end{array}$ \\
\hline & $\Delta \mathrm{T} 14$ & -0.8 & 2.5 & 3.4 & 4.8 & 2.0 & 1.8 & 2.5 & 0.5 & 0.5 & 2.9 & 3.6 & 0.4 & 2.0 \\
\hline
\end{tabular}

Примечание. Т11, Т12, Т13, Т14 - среднемесячная температура за 2011, 2012, 2013 и 2014 г. соответственно; $\Delta \mathrm{T}-$ отклонение среднемесячной температуры от средней за период 2001-2010 гг.

Пристань -8 мес, а на ГМС Сосуново - только 6 мес. В 2013 г. отрицательные отклонения температуры воздуха фиксируются на всех станциях с января по май (за исключением ГМС Сосуново). В 2014 г. почти на всех станциях с марта по июль и в ноябре отмечены положительные отклонения температуры воздуха. Но рекорд в 2014 г. был установлен на м. Сосуново, где произошло стремительное повышение температуры с февраля по декабрь с максимумом в апреле. В январе на всех станциях произошло понижение температуры воздуха, которое распространилось и на фев- раль, август и декабрь, исключая ГМС Сосуново.

Из анализа данных по температуре воздуха следует, что в 2011-2012 гг. воздух был наиболее прогрет на ГМС Владивосток, а в 20132014 гг. - на ГМС Сосуново. Причем ГМС Сосуново стало рекордсменом по повышению температуры и воды, и воздуха в 2014 г. В распределении температуры воздуха за эти 4 года можно отметить интересную особенность: на всех станциях в январе наблюдались только отрицательные отклонения. Зимние температуры воздуха по данным гидрометеостанций за период с 2011 по 2014 г. 
в основном оказались ниже средней десятилетия, т. е. зимы стали холоднее. Из летних месяцев выделяется июль, в который за 4 года повышение температуры произошло на всех без исключения станциях. Также и в осенние месяцы, особенно в ноябре, отмечено преобладание положительных аномалий температуры воздуха.

\section{ЗАКЛЮЧЕНИЕ}

В целом во временном ходе среднегодовых значений температуры воды и температуры воздуха вдоль побережья Приморья за период наблюдений с 1930 по 2014 г. выявлен значимый на 5\%-ном уровне тренд. Исключение составляет ГМС Находка, где в ходе температуры воды за этот период тренд не выявлен. Наблюдаемый рост среднегодовой температуры воздуха свидетельствует об общем увеличении температурного фона исследуемого района.

Анализ различий в температурах воды и воздуха между десятилетиями по сумме отклонений показал, что в целом на юге Приморья в юго-западной и юго-восточной частях зал. Петра Великого более теплыми были 2000-е гг., а в центральной части залива - 1990-е. На восточном побережье Приморского края картина распределения температуры иная - температура воды выше в 1990-е гг., а температура воздуха в 2000-е гг., что объясняется, по всей видимости, особенностями местной циркуляции вод.

При сравнении годового хода температуры воды и воздуха с 2011 по 2014 г. между собой можно отметить, что в 2014 г. с марта по июль практически на всех станциях произошел рост температуры воды, причем наибольшее повышение температуры и воды, и воздуха произошло на ГМС Сосуново. Зимние температуры воздуха по данным гидрометеостанций в последние годы снизились, т. е. зимы стали холоднее. Из летних месяцев выделяется июль, в который за 4 года повышение температуры произошло на всех без исключения станциях. Также и в осенние месяцы, особенно в ноябре, отмечено преобладание положительных аномалий температуры воздуха.

\section{ЛИТЕРАТУРА}

Волков Ю. Н., Калашников Б. М. Эль-Ниньо: идентификация и возможность прогнозирования // Тр. ДВНИГМИ. 1990. Вып. 136. С. 158-172.

Гайко Л. А. Многолетняя изменчивость температуры воды и воздуха у российского побережья Японского моря по данным гидрометеорологических станций // Океанологические исследования дальневосточных морей и северо-западной части Тихого океана. Владивосток : Дальнаука, 2013. Кн. 1. С. 64-78.
Гайко Л. А. Особенности гидрометеорологического режима прибрежной зоны залива Петра Великого (Японское море). Владивосток : Дальнаука, 2005. 151 с.

Гайко Л. А. Особенности температурного режима заливов Восток и Находка (юго-восточная часть залива Петра Великого) // Современное состояние и тенденции изменения природной среды залива Петра Великого Японского моря / отв. ред. А. С. Астахов, В. Б. Лобанов. М. : ГЕОС, 2008. С. 97-110.

Гайко Л. А. Температурные флуктуации в прибрежной зоне залива Петра Великого за последние десятилетия (Японское море) // Естественные и технические науки. 2015. № 10. С. 234-239.

Гайко Л. А. Тенденция изменчивости температуры воды и воздуха в прибрежных районах северозападной части Японского моря // Дальневосточные моря России. Кн. 1: Океанологические исследования. М. : Наука, 2007. С. 307-332.

Данченков М. А., Фельдман К. Л., Файман П. А. Температура и соленость вод залива Петра Великого // Гидрометеорология и экология Дальнего Востока : темат. вып. ДВНИГМИ. Владивосток : Дальнаука, 2003. № 4. С. 10-25.

Жабин И. А., Грамм-Осипова О. Л., Юрасов Г. И. Ветровой апвеллинг у северо-западного побережья Японского моря // Метеорология и гидрология. 1993. № 10. С. $82-86$.

Изменение климата, 2001 г. Обобщенный доклад / под ред. Роберта Т. Уотсона // Третий докл. МГЭИК об оценке. Межправит. группа экспертов по изменен. климата. 2003. Т. 4. 220 с.

Климат Владивостока. Л. : Гидрометеоиздат, 1983. $248 \mathrm{c}$.

Смолянкина Т. В. Многолетняя изменчивость аномалий давления, широты и долготы центров действия атмосферы Азиатско-Тихоокеанского региона // Тр. ДВНИГМИ, темат. вып. № 2, 1999. С. 10-16.

Юрасов Г. И., Яричин В.Г. Течения Японского моря. Владивосток : ДВО АН СССР, 1991. 176 с.

Climate Change. Synthesis report / ed. by Robert T. Watson / 2003 // IPCC third assessment report. Intergovernmental panel on climate change. 2001. Vol. 4. 220 p.

Gayko L. A. Water and air temperature variability along the coast of Primorye (Japan/East Sea) // Current Development in Oceanography, 2012. Vol. 5. Iss. 2. P. 49-58.

IPCC, 2001: Climate Change 2001: Synthesis Report. A Contribution of Working Groups I, II, and III to the Third Assessment Report of the Integovernmental Panel on Climate Change, R. T. Watson, and the Core Writing Team (eds.). Cambridge : Cambridge University Press ; New York, 2001. 398 p.

IPCC, 2007: Climate Change 2007: The Physical Science Basis. Contribution of Working Group I to the Fourth Assessment Report of the Intergovernmental Panel on Climate Change [Solomon, S., D. Qin, M. Manning, Z. Chen, M. Marquis, K. B. Averyt, M. Tignor and H. L. Miller (eds.)]. Cambridge University Press, Cambridge, United Kingdom and New York, NY, USA, 2007. 996 p. 


\title{
TEMPERATURE CHANGES IN AIR AND WATER ALONG THE COAST OF PRIMORSKY KRAI IN THE MODERN PERIOD (North-Western Part of the Sea of Japan)
}

\author{
L. A. Gayko \\ Pacific Oceanological Institute n. a.V. I. Ilyichev, FEB RAS, Vladivostok
}

The paper presents the analysis of the mean annual water and air temperature variability by the data from coastal weather stations in Primorye over the observation period from 1930 to 2014, the comparative analysis of the mean monthly temperatures variability over the last two decades, and the comparison of temperatures in each of the four years from 2011 to 2014. The results of the research conducted expose the increase in mean annual temperatures of water and air along the entire coast of Primorye during the period under review but in some years their average monthly values can fluctuate.

Keywords: air temperature, climate change, coastal weather station, Primorye, Sea of Japan, temperature trend, water temperature.

\section{REFERENCES}

Climate Change, 2001, Synthesis Report, Edited by Robert T. Watson, 2003, IPCC third Assessment Report, Intergovernmental Panel on Climate Change, 4 [In Russian].

Climate of Vladivostok, 1983, Leningrad, Gidrometeoizdat [In Russian].

Danchenkov, M. A.; Feldman, K. L.; Fayman, P. A., 2003, Water Temperature and Salinity in Peter-the-Great Bay, Hydrometeorology and Ecology of the Far East, FERHRI Issues, Spec. Iss. 4, Vladivostok, Dalnauka, 1025 [In Russian].

Gayko, L. A., 2005, Peculiarities of Hydrometeorological Regime of the Coastal Zone in the Peter-the-Great Bay (Sea of Japan), Vladivostok, Dalnauka [In Russian].

Gayko, L. A., 2007, Tendency of Water and Air Temperature Fluctuations in the Coastal Zone of the NorthWestern Part of the Sea of Japan, Far East Seas of Russia, Book 1, Oceanological Research, Moscow, Nauka, 307332 [In Russian].

Gayko, L. A., 2008, Temperature Mode Peculiarities in the Vostok Bay and the Nakhodka Bay (Southeastern Part of the Peter-the-Great Bay), Current Environmental Condition and Tendencies of Its Change in the Peterthe-Great Bay, Sea of Japan, Moscow, GEOS, 97-110 [In Russian].

Gayko, L. A., 2012, Water and Air Temperature Variability along the Coast of Primorye (Japan/East Sea), Current Development in Oceanography, 5, Iss. 2, 49-58.

Gayko, L. A., 2013, Long-Term Variability of the Water and Air Temperature at the Russian Coast of the Sea of Japan, by the Data from Meteorological Stations, Oceanographic Studies of the Far East Seas and the Northwest
Pacific, Book 1, Vladivostok, Dalnauka, 64-78 [In Russian].

Gayko, L. A., 2015, Temperature Fluctuations in the Coastal Zone of Peter-the-Great Bay (Sea of Japan) in the Last Decade, Yestestvenniye i Tekhnicheskiye Nauki, 10, 234-239 [In Russian].

IPCC, 2001: Climate Change 2001: Synthesis Report. A Contribution of Working Groups I, II, and III to the Third Assessment Report of the Integovernmental Panel on Climate Change, R. T. Watson, and the Core Writing Team (eds.), Cambridge, Cambridge University Press, New York.

IPCC, 2007: Climate Change 2007: The Physical Science Basis, Contribution of Working Group I to the Fourth Assessment Report of the Intergovernmental Pa-nel on Climate Change, Eds. S. Solomon, D. Qin, M. Manning, Z. Chen, M. Marquis, K. B. Averyt, M. Tignor, and H. L. Miller, Cambridge University Press, Cambridge, United Kingdom, and New York, NY, USA.

Smolyankina, T. V., 1999, Perennial Variability of Pressure, Latitude, and Longitude Anomalies of Atmospheric Action Centers in Asia-Pacific, FERHRI Issues, Spec. Iss. 2, 10-16 [In Russian].

Volkov, Yu. N.; Kalashnikov, B. M., 1990, El-Nino: Identification and Possibility of Forecasting, FERHRI Issues, 136, 158-172 [In Russian].

Yurasov, G. I.; Yarichin, V. G., 1991, Currents of the Sea of Japan, Vladivostok, DVO AN SSSR [In Russian].

Zhabin, I. A.; Gramm-Osipova, O. L.; Yurasov, G. I., 1993, Wind Upwelling at the Northwestern Coast of the Sea of Japan, Meteorologiya i Gidrologiya, 10, 82-86 [In Russian]. 